\title{
Glasgow Prognostic Score predicts prognosis of intrahepatic cholangiocarcinoma
}

\author{
QUN-XIONG PAN, ZI-JIAN SU, JIAN-HUA ZHANG, CHONG-REN WANG and SHAO-YING KE
}

\author{
Department of Oncological Surgery, Quanzhou First Affiliated Hospital \\ of Fujian Medical University, Quanzhou, Fujian 362000, P.R. China
}

Received May 6, 2016; Accepted September 26, 2016

DOI: $10.3892 / \mathrm{mco} .2017 .1166$

\begin{abstract}
High Glasgow Prognostic Score (GPS) has been associated with poor prognosis in patients with lung, ovarian, colorectal and renal cancer, as well as hepatocellular carcinoma. The aim of this study was to investigate the prognostic value of GPS in patients with intrahepatic cholangiocarcinoma (ICC) undergoing partial hepatectomy. A total of 72 patients with pathologically confirmed ICC were classified according to their GPS scores assigned based on the preoperative levels of C-reactive protein (CRP) and albumin. Their clinicopathological data were retrospectively assessed using univariate and multivariate analysis to determine their association with overall survival and recurrence. High GPS scores in ICC patients were associated with preoperative levels of CRP $(\mathrm{P}<0.001)$ and albumin $(\mathrm{P}<0.001)$, frequency of ascites accumulation $(\mathrm{P}=0.035)$, lymph node metastasis $(\mathrm{P}=0.002)$ and tumour size $(\mathrm{P}=0.005)$. On univariate analysis, preoperative levels of CRP $(\mathrm{P}<0.001)$, albumin $(\mathrm{P}=0.016)$ and carbohydrate antigen 19-9 $(\mathrm{P}=0.038)$, hepatitis $\mathrm{B}$ virus (HBV) positivity $(\mathrm{P}=0.009)$, occurrence of lymph node metastasis $(\mathrm{P}=0.001)$, Child-Pugh class $\mathrm{B}(\mathrm{P}=0.013)$ and high tumour-node-metastasis $(\mathrm{TNM})$ stage $(\mathrm{P}=0.002)$ were found to be associated with the 1 - and 3 -year overall survival. Multivariate analysis suggested that GPS score (HR=2.037, 95\% CI: 1.092-3.799, $\mathrm{P}=0.025)$, TNM classification (HR=2.000, 95\% CI: 1.188-3.367, $\mathrm{P}=0.009)$ and HBV positivity (HR=0.559 95\% CI: $0.328-0.953, \mathrm{P}=0.032$ ) were independently associated with patient survival. High GPS scores also predicted ICC recurrence. In conclusion, our results demonstrated that GPS may serve as an independent marker of prognosis in patients with ICC following partial hepatectomy.
\end{abstract}

Correspondence to: Dr Qun-Xiong Pan, Department of Oncological Surgery, Quanzhou First Affiliated Hospital of Fujian Medical University, 250 Anji Road, Fengze, Quanzhou, Fujian 362000, P.R. China

E-mail: 710262737@qq.com

Key words: Glasgow Prognostic Score, intrahepatic cholangiocarcinoma, prognostic marker

\section{Introduction}

Intrahepatic cholangiocarcinoma (ICC) is an intrahepatic malignancy arising from the biliary epithelium in the intrahepatic bile duct from the segmental and area ducts and their finer branches to the small bile ducts and ductules $(1,2)$. ICC is the second most frequent intrahepatic primary liver tumour after hepatocellular carcinoma (3), accounting for $5-10 \%$ of primary liver cancer cases (4). Of note, the global incidence of ICC has been steadily increasing over the last 30 years (4). From the early 1970 s to 1999 , the ICC incidence in United States and China increased by $>150 \%(4,5)$. Due to a lack of clinical symptoms and appropriate markers for early diagnosis, ICC is usually diagnosed at an advanced stage (4), mostly with local invasion, liver parenchymal and lymph node metastases, leading to a poor outcome following surgical removal, which is currently the only curative option $(6,7)$. The increasing incidence of ICC, its poor prognosis and lack of treatment options necessitate further studies on its risk factors, early diagnostic markers and prognostic factors.

A number of prognostic factors have previously been reported for ICC, including liver function, vascular invasion, tumour-node-metastasis (TNM) classification and lymph node metastasis $(8,9)$; however, there is little consensus regarding the appropriate prognostic factors and thresholds $(10,11)$. Accumulating evidence indicates the prospective of inflammation-based parameters as prognostic factors (12). This is supported by the wide range of associations between inflammation and tumour initiation, invasion and metastasis $(13,14)$. Tumour infiltration and infiltrating lymphocytes in the tumour microenvironment induce the production of a repertoire of cytokines and inflammatory factors (15); in turn, interleukin (IL)-6, tumour necrosis factor (TNF) and neutrophil accumulation due to the systemic inflammation, enhance tumour growth, invasion and metastasis (16-19). Targeting IL-6 and TNF to interrupt their signalling cascades has been demonstrated to reduce angiogenesis, myeloid cell infiltration and tumour growth $(20,21)$.

Over the past decade, a number of parameters and scoring systems have been developed based on systemic inflammation, which may be evaluated by the serum levels of platelets, neutrophils, lymphocytes, albumin and C-reactive protein (CRP), to assess the prognosis of malignant solid tumours. These include the Glasgow Prognostic Score (GPS), which is based on serum 
CRP and albumin levels (22-28), neutrophil-to-lymphocyte ratio (NLR) $(29,30)$, platelet-to-lymphocyte ratio $(31,32)$, prognostic nutritional index $(33,34)$, and prognostic index $(34,35)$.

Certain inflammation-based parameters and scoring systems were previously shown to reliably predict the prognosis of cholangiocarcinoma. Preoperative NLR is correlated with the overall survival of ICC patients, and NLR $>5$ is an independent risk factor for recurrence (36). GPS is an independent prognostic factor for extrahepatic cholangiocarcinoma according to a study on 62 patients (37). The aim of the present study was to investigate the feasibility of using preoperative GPS as an ICC prognostic factor.

\section{Patients and methods}

Patient selection. The ICC subjects were recruited among patients who had undergone partial hepatectomy performed by the same group of surgeons at the Department of Oncological Surgery, Quanzhou First Hospital, Fujian Medical University (Quanzhou, China) from June, 2005 to September, 2011. All selected patients had complete long-term follow-up records and their clinical background information was available for retrospective analysis. Patients with preoperative metastasis, or those undergoing systemic chemotherapy, transcatheter arterial chemoembolization, or local ablation therapy, as well as patients with acute inflammation or rheumatoid arthritis, were excluded. Blood tests were performed 3 days prior to surgery and ICC was confirmed by postoperative histopathological examination.

The present study complied with the standards of the Helsinki Declaration on human research ethics and was approved by the Institutional Ethics Board of Fujian Medical University. Written informed consent from the investigated patients was not obtained due to the retrospective nature of this study. All data were analysed anonymously.

Follow-up survey and data collection. The follow-up surveys were conducted monthly to quarterly within 2 years after surgery, quarterly to half-yearly between 2 and 5 years, and halfyearly thereafter. The survey included comprehensive medical history, measurement of carbohydrate antigen 19-9 (CA19-9) levels and imaging surveillance by chest radiography, abdominal Doppler ultrasonography and computed tomography. Survival was calculated in months from the date of surgery to death, and disease-free survival as months from the date of surgery to recurrence. Recurrence was defined as any unequivocal occurrence of new cancer foci during imaging surveillance or histopathological analysis. The follow-up was continued for $\leq 67$ months (mean, 24 months), ending on September 1, 2014 for all 72 patients. Following institutional ethics approval, the complete medical files, including images, clinical pathological materials, and follow-up records, were archived in a database for retrospective analysis.

Clinical data, biochemical parameters and GPS. The size and number of tumours and presence of vascular invasion were assessed based on postoperative pathological outcomes. Serum CRP concentration was measured by a nephelometric immunoassay on a Beckman Coulter immunochemistry system (IMMAGE 800; Beckman Coulter, Inc., Brea, CA,
USA). Serum CA19-9 levels were assessed by electro-chemiluminescent microparticle immunoassay (Roche Diagnostics, Shanghai, China), and a level $>37 \mathrm{U} / \mathrm{ml}$ was considered to be positive. Biochemical parameters, such as alanine aminotransferase (ALT), aspartate aminotransferase (AST), total bilirubin (TB) and albumin, were determined using a Beckman Coulter LX-20 clinical chemistry analyser (Beckman Coulter, Inc.). Hepatitis B virus (HBV) was quantified by chemiluminescence using an Architect i2000SR immunoassay analyser (Abbott Diagnostics, Lake Forest, IL, USA). The tumours were staged according to the 7th edition of TNM system (38) issued by the American Joint Committee on Cancer/International Union Against Cancer, and graded following the Edmondson system (39).

GPS was allocated as previously described, combining preoperative serum CRP and albumin levels. Patients with elevated CRP level (>10 mg/l) and hypoalbuminemia $(<35 \mathrm{~g} / \mathrm{l})$ were scored as 2 , patients with only one of the two biochemical abnormalities were scored as 1 , and patients with neither of the two abnormalities were scored as $0(22,23)$.

Statistical analysis. All the statistical tests were performed using IBM SPSS Statistics software v.19.0 (IBM SPSS Inc., Armonk, NY, USA). The $\chi^{2}$ test, Fisher's exact probability test and Student's t-test were used for comparison between groups. The non-parametric Mann-Whitney U test was used when variables in groups were not homogeneous. Prognosis was evaluated by 3 - and 5-year overall and disease-free survival after surgery. Kaplan-Meier cumulative survivals were calculated and groups with different GPS scores were compared using the log-rank test. The Cox proportional hazards model was used for multivariate analysis and a threshold $\alpha=0.05$ was used.

\section{Results}

Patient characteristics. The median age of the 72 patients was 55 years (mean \pm standard deviation, 53.26 \pm 11.05 years); 29 of the patients were male and 43 female (Table I). A total of 63 and 9 patients were classified as Child-Pugh A and $\mathrm{B}$, respectively; there were no class $\mathrm{C}$ patients. A total of $34(47.2 \%)$ patients were positive for antibodies against HBV. The overall 1-, 3- and 5-year postoperative survival was $55.56,29.20$ and $8.33 \%$, respectively, with a median survival of 34 months.

A total of $14(19.4 \%)$ patients exhibited elevated CRP levels (>10 g/l), and 16 (22.2\%) patients had hypoalbuminemia (serum albumin $<35 \mathrm{~g} / \mathrm{l}$ ). As a result, 49 (68.1\%) patients were scored a GPS of 0, 16 (22.2\%) patients were scored a GPS of 1 and 7 (9.7\%) patients were scored a GPS of 2 (Table II). There was no significant difference between the GPS groups in terms of age $(\mathrm{P}=0.191)$, gender $(\mathrm{P}=0.209)$, ALT $(\mathrm{P}=0.105)$, $\alpha$-fetoprotein $(\mathrm{P}=0.588)$, AST $(\mathrm{P}=0.204)$, total bilirubin $(\mathrm{P}=0.816), \mathrm{HBV}$ positivity $(\mathrm{P}=0.324), \mathrm{CA}-199(\mathrm{P}=0.824)$, tumour number $(\mathrm{P}=0.850)$ and vascular invasion $(\mathrm{P}=0.234)$. However, significant differences were found between different GPS groups in the preoperative levels of CRP $(\mathrm{P}<0.001)$ and albumin $(\mathrm{P}<0.001)$, frequency of ascites accumulation $(\mathrm{P}=0.035)$, lymph node metastasis $(\mathrm{P}=0.002)$ and tumour size $(\mathrm{P}=0.005)$. A higher GPS was also correlated with Child-Pugh class $(P=0.003)$ and TNM stage $(P=0.048)$. Patients with 
Table I. Clinicopathological characteristics of the patients.

\begin{tabular}{|c|c|c|c|c|c|}
\hline Characteristics & No. & Percentage & Characteristics & No. & Percentage \\
\hline Gender & & & TNM classificat & & \\
\hline Male & 29 & 40.30 & I & 45 & 62.50 \\
\hline Female & 43 & 59.70 & II & 24 & 33.33 \\
\hline Age (years) & & & III & 3 & 4.20 \\
\hline Median & 55 & & GPS score & & \\
\hline Mean \pm SD & $53.26 \pm 11.05$ & & 0 & 49 & 68.10 \\
\hline Child-Pugh class & & & 1 & 16 & 22.20 \\
\hline A & 63 & 87.50 & 2 & 7 & 9.70 \\
\hline B & 9 & 12.50 & \multirow{2}{*}{\multicolumn{3}{|c|}{$\begin{array}{l}\text { CRP, C-reactive protein; HBsAg, hepatitis B surface antigen; } \\
\text { AFP, } \alpha \text {-fetoprotein; ALT, alanine aminotransferase; AST, aspartate } \\
\text { aminotransferase; CA19-9, carbohydrate antigen 19-9; TNM, } \\
\text { tumour-node-metastasis; GPS, Glasgow Prognostic Score. } \\
\end{array}$}} \\
\hline $\begin{array}{l}\mathrm{CRP}(\mathrm{mg} / \mathrm{l}) \\
\leq 10 \\
>10\end{array}$ & $\begin{array}{l}58 \\
14\end{array}$ & $\begin{array}{l}80.60 \\
19.40\end{array}$ & & & \\
\hline
\end{tabular}

Albumin (g/l)

$<35$

$\geq 35$

HBV status

Positive

Negative

38

Vascular invasion

Yes

No

No. of tumours

1

$\geq 2$

55

17

Tumour size $(\mathrm{cm})$

$\leq 5$

$\operatorname{AFP}(\mathrm{ng} / \mathrm{ml})$

$<400$

$\geq 400$

30

$\operatorname{ALT}(\mathrm{U} / \mathrm{l})$

$\leq 40$

40

$>40$

32

AST (U/1)

$\leq 40$

39

$>40$

31

$>17.1$

Ascites

Negative

Positive

63

CA19-9 (U/1)

Lymph node metastases

Yes

No
Table I. Continued

22.20

77.80

47.20

52.80

44.40

55.60

76.40

23.60

72.20

27.80

58.30

41.70

55.60

44.40

54.20

45.80

56.90

43.10

87.50

12.50

37.50

62.50

higher GPS score (1 or 2) had higher serum CRP levels, lower albumin levels, and were more likely classified as Child-Pugh class B and higher TNM stage, compared with GPS 0 patients; they also more frequently presented with ascites and lymph node metastasis (Table II).

GPS predicts overall survival. The 1- and 3-year overall survival rates of ICC patients with a GPS score of 0 (GPS-low) were 69.1 and $40.7 \%$, respectively. The 1- and 3-year overall survival rates of ICC patients with a GPS score of 1 were 31.3 and $6.3 \%$, respectively; for patients with a GPS score of 2 , these rates decreased to 28.6 and $0 \%$, respectively. Kaplan-Meier analysis with a log-rank test indicated a significant decrease in the survival rate of patients with higher GPS scores (1 or 2) compared with the GPS-low group (Fig. 1, P<0.001). However, there was no significant difference in survival between patients with a GPS score of 1 and $2(\mathrm{P}=0.428)$; thus, these two populations were merged into a GPS-high group and compared with the GPS-low patients. The 1- and 3-year overall survival rates of patients from the GPS-high group were 30.4 and $10.4 \%$, respectively, which were significantly lower compared with those of the GPS-low group (Fig. 2, P<0.001).

On univariate analysis to assess the other prognostic factors, preoperative CRP $(\mathrm{P}<0.001)$, albumin $(\mathrm{P}=0.016)$ and CA19-9 $(\mathrm{P}=0.038)$ levels were found to be significantly associated with the 1- and 3-year overall survival. Occurrence of lymph node metastasis $(\mathrm{P}=0.001)$, HBV positivity $(\mathrm{P}=0.009)$, Child-Pugh class $\mathrm{B}(\mathrm{P}=0.013)$ and high TNM stage $(\mathrm{P}=0.002)$ also predicted poor survival in ICC patients.

Due to the association of GPS with CRP and albumin levels, its correlation with patient survival was assessed in a multivariate analysis using a Cox proportional hazards model. Also included in the multivariate analysis were 5 variables other than CRP and albumin, such as CA19-9, occurrence of lymph node metastasis, positivity for HBV, Child-Pugh class and TNM stage, which were correlated with patient survival based on the univariate analysis (Table III). The multivariate analysis revealed that GPS $(\mathrm{HR}=2.037,95 \% \mathrm{CI}$ : 1.092-3.799, $\mathrm{P}=0.025)$, TNM classification $(\mathrm{HR}=2.000$, 29.20 70.80 
Table II. Association of GPS score with clinicopathological characteristics in patients undergoing hepatectomy.

\begin{tabular}{|c|c|c|c|c|c|}
\hline Characteristics & Overall $(\mathrm{n}=72)$ & GPS $=0 \quad(n=49)$ & GPS $=1 \quad(n=16)$ & GPS=2 (n=7) & P-value \\
\hline \multicolumn{6}{|l|}{ Age (years) } \\
\hline Mean \pm SD & $53.26 \pm 11.05$ & $53.51 \pm 11.16$ & $49.88 \pm 13.00$ & $59.29 \pm 8.538$ & 0.191 \\
\hline Gender & & & & & 0.209 \\
\hline Male & 29 & 18 & 6 & 5 & \\
\hline Female & 43 & 31 & 10 & 2 & \\
\hline Child-Pugh class & & & & & 0.003 \\
\hline A & 63 & 47 & 12 & 4 & \\
\hline $\mathrm{B}$ & 9 & 2 & 4 & 3 & \\
\hline CRP (mg/l) & $8.321 \pm 16.33$ & $2.34 \pm 2.52$ & $12.07 \pm 10.24$ & $41.65 \pm 34.88$ & $<0.001$ \\
\hline Albumin (g/l) & $36.99 \pm 5.05$ & $39.34 \pm 3.12$ & $32.93 \pm 5.31$ & $29.90 \pm 2.61$ & $<0.001$ \\
\hline \multicolumn{6}{|l|}{ HBV status } \\
\hline Positive & 34 & 26 & 6 & 2 & 0.324 \\
\hline Negative & 38 & 23 & 10 & 5 & \\
\hline Vascular invasion & & & & & 0.234 \\
\hline Yes & 40 & 26 & 8 & 6 & \\
\hline No & 32 & 23 & 8 & 1 & \\
\hline Tumour size $(\mathrm{cm})$ & & & & & 0.005 \\
\hline Mean \pm SD & $5.82 \pm 3.42$ & $5.01 \pm 3.22$ & $7.06 \pm 3.37$ & $8.71 \pm 2.81$ & \\
\hline No. of tumours & & & & & 0.850 \\
\hline 1 & 55 & 37 & 13 & 5 & \\
\hline$\geq 2$ & 17 & 12 & 3 & 2 & \\
\hline \multicolumn{6}{|l|}{$\mathrm{AFP}(\mathrm{ng} / \mathrm{ml})$} \\
\hline Mean \pm SD & $4,130.0 \pm 10,926.52$ & $4,645.83 \pm 12,107.70$ & $3,088.98 \pm 7,596.47$ & $253.63 \pm 5,536.98$ & 0.588 \\
\hline \multicolumn{6}{|l|}{$\operatorname{ALT}(\mathrm{U} / \mathrm{l})$} \\
\hline Mean \pm SD & $83.24 \pm 166.23$ & $60.12 \pm 73.20$ & $160.81 \pm 323.78$ & $67.71 \pm 39.13$ & 0.105 \\
\hline \multicolumn{6}{|l|}{$\operatorname{AST}(\mathrm{U} / \mathrm{l})$} \\
\hline Mean \pm SD & $85.26 \pm 153.28$ & $63.40 \pm 74.93$ & $140.48 \pm 295.08$ & $106.67 \pm 51.43$ & 0.204 \\
\hline \multicolumn{6}{|l|}{ Total bilirubin $(\mu \mathrm{mol} / \mathrm{l})$} \\
\hline Mean \pm SD & $24.58 \pm 26.41$ & $23.96 \pm 20.62$ & $28.89 \pm 46.83$ & $21.92 \pm 15.63$ & 0.816 \\
\hline CA 19-9 (U/1) & & & & & 0.824 \\
\hline$<37$ & 27 & 19 & 5 & 3 & \\
\hline$\geq 37$ & 45 & 30 & 11 & 4 & \\
\hline Ascites & & & & & 0.035 \\
\hline Negative & 63 & 44 & 15 & 4 & \\
\hline Positive & 9 & 5 & 1 & 4 & \\
\hline Lymph node metastases & & & & & 0.002 \\
\hline Yes & 21 & 8 & 9 & 4 & \\
\hline No & 51 & 41 & 7 & 3 & \\
\hline TNM classification & & & & & 0.048 \\
\hline I & 3 & 3 & 0 & 0 & \\
\hline II & 24 & 21 & 3 & 0 & \\
\hline III & 45 & 25 & 13 & 7 & \\
\hline
\end{tabular}

Bold print indicates statistical significance. CRP, C-reactive protein; HBsAg, hepatitis B surface antigen; AFP, $\alpha$-fetoprotein; ALT, alanine aminotransferase; AST, aspartate aminotransferase; CA 19-9, carbohydrate antigen 19-9; TNM, tumour-node-metastasis; GPS, Glasgow Prognostic Score.

95\% CI: $0.328-0.953, \mathrm{P}=0.032)$ were independently associated with overall survival (Table III).
GPS correlates with the recurrence of ICC. Analysis of the time and frequency of ICC recurrence following hepatectomy 


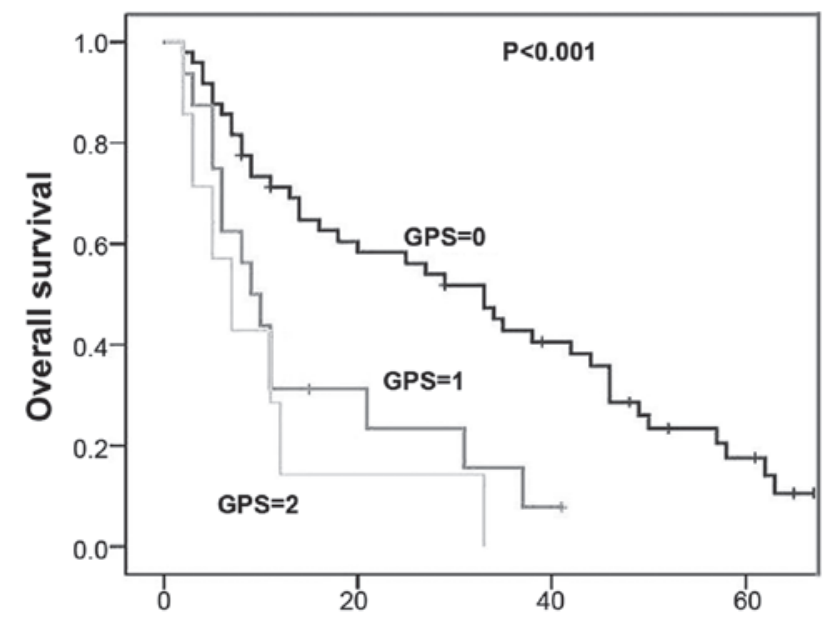

Time after surgery (months)

Figure 1. Kaplan-Meier analysis of overall survival of intrahepatic cholangiocarcinoma patients. The cases were assigned to Glasgow Prognostic Score (GPS) 0, 1 and 2 groups. There was a significant decrease in the survival rate of patients with higher GPS scores (1 or 2) compared with the GPS-low (0) group $(\mathrm{P}<0.001)$. However, no significant difference in survival was observed between patients with a GPS score of 1 and $2(\mathrm{P}=0.428)$.

A

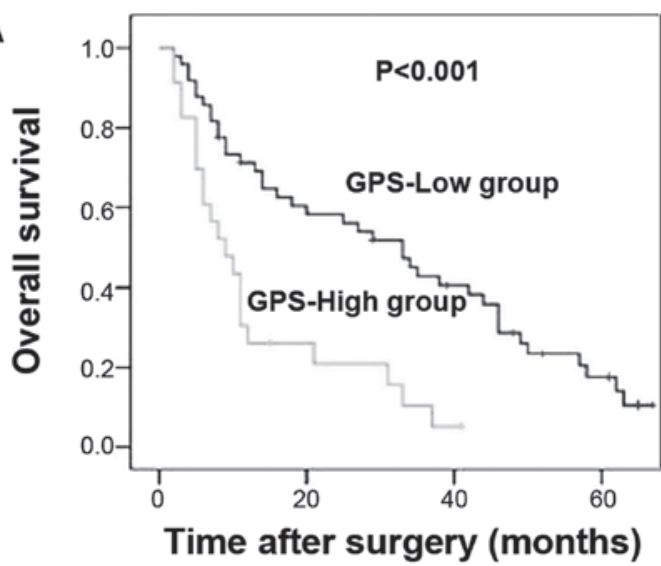

B

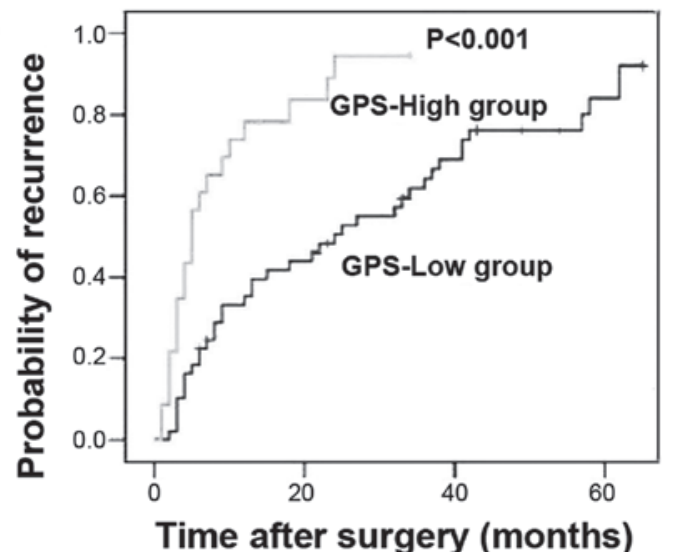

Figure 2. Kaplan-Meier survival curves showing the differences in (A) survival and (B) recurrence between the two Glasgow Prognostic Score (GPS) groups (0 vs.1 or 2$)$ in patients with intrahepatic cholangiocarcinoma (ICC). (A) The 1- and 3-year overall survival rates of patients in the GPS-high group were 30.4 and $10.4 \%$, respectively, which were significantly lower compared with the GPS-low group. (B) The GPS-low patients had a 35.3 and $64.7 \%$ risk of developing recurrent disease after 1 and 3 years, respectively, whereas ICC recurred in $78.3 \%$ of the GPS-high patients after 1 year and $100 \%$ after 3 years, indicating a significantly poorer progression-free survival. unveiled a significantly higher recurrence frequency among the GPS-high patients compared with that among the GPS-low patients. The GPS-low patients had a 35.3 and $64.7 \%$ risk of developing recurrent disease after 1 and 3 years, respectively, whereas ICC recurred in $78.3 \%$ of the GPS-high patients after 1 year and $100 \%$ after 3 years, indicating a significantly poorer progression-free survival (Fig. 2, $\mathrm{P}<0.001$ ). Multivariate analysis suggested that GPS ( $\mathrm{HR}=1.969,95 \% \mathrm{CI}$ : 1.014-3.822, $\mathrm{P}=0.045)$, TNM classification $(\mathrm{HR}=2.816$, 95\% CI: $1.565-5.066, \mathrm{P}=0.001)$ and $\mathrm{HBV}$ positivity $(\mathrm{HR}=0.426$, $95 \%$ CI: $0.232-0.785, \mathrm{P}=0.006)$ were independent prognostic factors for ICC recurrence (Table III).

\section{Discussion}

An association between inflammation and ICC progression has been established. The risk factors for ICC incidence vary with different geographic regions: In Asia, ICC is mainly due to infection by pathogens including liver flukes and hepatitis $B$ and $\mathrm{C}$ viruses; in Western countries, it may be attributed to chronic inflammation, primary sclerosing cholangitis, obesity, hepatolithiasis, bacterial infection and bile stasis-related chronic cholangitis (40). Chronic inflammation and biliary irritation are, however, commonly shared among these diseases (40). These support recent findings that inflammation-based scores or parameters may be used as prognostic markers for patients with cholangiocarcinoma $(36,37)$. In this study, we demonstrated that the inflammation-based prognostic score, GPS, is associated with the recurrence and overall survival of ICC patients and may be used as an independent prognostic marker.

Analysis of clinicopathological data of 72 ICC patients indicated that GPS classification precisely reflects the preoperative CRP and albumin levels, Child-Pugh class, tumour size, TNM classification, and the occurrence of ascites and lymph node metastasis. Patients with high GPS scores (1 or 2) exhibited a significantly shorter overall survival compared with those with a low GPS score (0), although no statistically significant difference was observed between patients with GPS scores of 1 and 2, which is likely due to the limited number of patients in these two groups. Our analysis using the Cox hazards model suggested that GPS, as well as TNM classification and HBV positivity, is an independent prognostic factor for the recurrence of ICC and the overall patient survival.

Although GPS has frequently been associated with the prognosis of solid tumours, such as lung $(22,23)$, liver $(27,28)$, kidney (26), ovarian (24), colorectal $(25)$, gastric $(41,42)$ and pancreatic cancer (43), the association has yet to be fully elucidated. One component of the GPS score, CRP, is an acute phase protein synthesized by hepatocytes in response to inflammation, infection, tissue damage and cancer, reflecting systemic inflammation (44). Although there is no causal association between elevated CRP and cancer development, the cytokines that mediate CRP, such as IL-1, IL-6 and TNF, are key pro-inflammatory factors in hepatobiliary inflammation and cancer (45). For example, IL-6 contributes to the growth of malignant cholangiocytes by affecting the promoter methylation and expression of several genes, including epidermal grow th factor receptor (46). IL-6 also promotes malignant cholangiocyte growth by activating the mitogen-activated protein kinase pathway and enhancing the expression of the 
Table III. Univariate and multivariate analyses of clinicopathological factors for overall and disease-free survival.

\begin{tabular}{|c|c|c|c|c|c|c|c|c|}
\hline \multirow[b]{3}{*}{ Variables } & \multicolumn{4}{|c|}{ Overall survival } & \multicolumn{4}{|c|}{ Disease-free survival } \\
\hline & \multicolumn{2}{|c|}{ Survival rate $(\%)$} & \multirow{2}{*}{$\begin{array}{c}\text { Univariate } \\
\mathrm{P} \text { value }\end{array}$} & \multirow{2}{*}{$\begin{array}{l}\text { Multivariate } \\
\text { HR }(95 \% \text { CI })\end{array}$} & \multicolumn{2}{|c|}{ Survival rate $(\%)$} & \multirow{2}{*}{$\begin{array}{l}\text { Univariate } \\
\mathrm{P} \text { value }\end{array}$} & \multirow{2}{*}{$\begin{array}{l}\text { Multivariate } \\
\text { HR }(95 \% \text { CI })\end{array}$} \\
\hline & 1-year & 3-year & & & 1-year & 3-year & & \\
\hline \multicolumn{9}{|l|}{ Gender } \\
\hline Male $(n=43)$ & 57.7 & 35.6 & 0.137 & & 47.5 & 16.1 & 0.120 & \\
\hline Female $(n=29)$ & 55.1 & 23.7 & & & 50.6 & 30.1 & & \\
\hline \multicolumn{9}{|l|}{ Age (years) } \\
\hline$<55(\mathrm{n}=36)$ & 50.0 & 26.8 & 0.293 & & 38.9 & 18.5 & 0.318 & \\
\hline$\geq 55(n=36)$ & 60.4 & 36.3 & & & 54.8 & 24.7 & & \\
\hline \multicolumn{9}{|l|}{ Child-Pugh class } \\
\hline$A(n=63)$ & 60.1 & 33.7 & 0.013 & & 52.0 & 28.4 & 0.005 & \\
\hline$B(n=9)$ & 22.2 & 0 & & & 15.3 & 0 & & \\
\hline \multicolumn{9}{|l|}{ CRP (mg/l) } \\
\hline$\leq 10(\mathrm{n}=58)$ & 65.2 & 36.9 & $<0.001$ & & 57.8 & 32.7 & $<0.001$ & \\
\hline$>10(n=14)$ & 14.3 & 7.1 & & & 7.1 & 0 & & \\
\hline \multicolumn{9}{|l|}{ Albumin (g/l) } \\
\hline$<35(\mathrm{n}=16)$ & 37.5 & 7.8 & 0.016 & & 25.0 & 0 & 0.007 & \\
\hline$\geq 35(\mathrm{n}=56)$ & 62.3 & 37.3 & & & 58.4 & 31.2 & & \\
\hline HBV status & & & & 0.032 & & & & 0.006 \\
\hline Positive $(n=34)$ & 67.6 & 47.2 & 0.009 & $(0.328-0.953)$ & 61.8 & 31.8 & 0.003 & $(0.232-0.785)$ \\
\hline Negative $(n=38)$ & 43.8 & 18.4 & & & 31.9 & 10.2 & & \\
\hline \multicolumn{9}{|l|}{ Vascular invasion } \\
\hline Yes $(n=40)$ & 54.3 & 30.6 & 0.879 & & 46.4 & 27.0 & 0.875 & \\
\hline No $(n=32)$ & 53.1 & 31.3 & & & 50.0 & 21.9 & & \\
\hline \multicolumn{9}{|l|}{ No. of tumours } \\
\hline $1(\mathrm{n}=55)$ & 54.2 & 31.5 & 0.838 & & 42.1 & 25.2 & 0.820 & \\
\hline$\geq 2(\mathrm{n}=17)$ & 52.9 & 29.4 & & & 47.1 & 212 & & \\
\hline \multicolumn{9}{|c|}{ Lymph node metastasis } \\
\hline Negative $(\mathrm{n}=51)$ & 62.3 & 38.1 & 0.001 & & 60.3 & 35.6 & 0.002 & \\
\hline Positive $(n=21)$ & 38.1 & 14.3 & & & 28.6 & 0 & & \\
\hline \multicolumn{9}{|l|}{ Tumour size (cm) } \\
\hline$\leq 5(n=20)$ & 69.6 & 44.7 & 0.054 & & 69.1 & 43.0 & 0.028 & \\
\hline$>5(n=52)$ & 49.5 & 29.8 & & & 43.8 & 17.7 & & \\
\hline \multicolumn{9}{|l|}{ AFP (ng/ml) } \\
\hline$<400(\mathrm{n}=43)$ & 62.1 & 39.2 & 0.082 & & 61.0 & 29.4 & 0.076 & \\
\hline$\geq 400(n=29)$ & 41.4 & 22.6 & & & 36.7 & 17.6 & & \\
\hline \multicolumn{9}{|l|}{$\operatorname{ALT}(\mathrm{U} / \mathrm{l})$} \\
\hline$\leq 40(n=40)$ & 59.7 & 31.9 & 0.622 & & 54.5 & 19.8 & 0.798 & \\
\hline$>40(n=32)$ & 52.9 & 33.1 & & & 46.2 & 26.0 & & \\
\hline \multicolumn{9}{|l|}{$\operatorname{AST}(\mathrm{U} / 1)$} \\
\hline$\leq 40(n=39)$ & 66.3 & 41.1 & 0.217 & & 61.0 & 25.7 & 0.166 & \\
\hline$>40(n=33)$ & 45.5 & 22.6 & & & 38.8 & 19.8 & & \\
\hline Total bilirubin $(\mu \mathrm{m}$ & & & & & & & & \\
\hline$\leq 17.1(\mathrm{n}=41)$ & 58.3 & 41.5 & 0.574 & & 55.4 & 26.7 & 0.716 & \\
\hline$>17.1(n=31)$ & 54.8 & 21.8 & & & 45.2 & 18.1 & & \\
\hline CA19-9 (U/1) & & & & & & & & \\
\hline$<37(\mathrm{n}=27)$ & 66.0 & 38.8 & 0.038 & & 62.0 & 32.5 & 0.046 & \\
\hline$\geq 37(n=45)$ & 46.6 & 24.0 & & & 44.1 & 16.0 & & \\
\hline
\end{tabular}


Table III. Continued.

\begin{tabular}{|c|c|c|c|c|c|c|c|c|}
\hline \multirow[b]{3}{*}{ Variables } & \multicolumn{4}{|c|}{ Overall survival } & \multicolumn{4}{|c|}{ Disease-free survival } \\
\hline & \multicolumn{2}{|c|}{ Survival rate $(\%)$} & \multirow{2}{*}{$\begin{array}{c}\text { Univariate } \\
\mathrm{P} \text { value }\end{array}$} & \multirow{2}{*}{$\begin{array}{l}\text { Multivariate } \\
\text { HR }(95 \% \text { CI) }\end{array}$} & \multicolumn{2}{|c|}{ Survival rate $(\%)$} & \multirow{2}{*}{$\begin{array}{l}\text { Univariate } \\
\mathrm{P} \text { value }\end{array}$} & \multirow{2}{*}{$\begin{array}{l}\text { Multivariate } \\
\text { HR }(95 \% \text { CI })\end{array}$} \\
\hline & 1-year & 3-year & & & 1-year & 3-year & & \\
\hline \multicolumn{9}{|l|}{ Ascites } \\
\hline Negative $(n=63)$ & 56.9 & 33.6 & 0.676 & & 50.4 & 24.7 & 0.597 & \\
\hline Positive $(n=9)$ & 53.3 & 20.0 & & & 40.0 & 15.2 & & \\
\hline \multicolumn{9}{|l|}{ TNM classification } \\
\hline $\mathrm{I}(\mathrm{n}=3)$ & 100 & 100 & 0.002 & $\begin{array}{c}0.009 \\
(1.1883 .367)\end{array}$ & 100 & 100 & $<0.001$ & $\begin{array}{c}0.001 \\
(1.565-5.066)\end{array}$ \\
\hline II $(n=24)$ & 70.1 & 48.8 & & & 65.2 & 34.5 & & \\
\hline III $(n=45)$ & 44.4 & 20.0 & & & 37.8 & 11.1 & & \\
\hline GPS & & & & 0.025 & & & & 0.045 \\
\hline $0(n=49)$ & 69.1 & 40.7 & $<0.001$ & $(1.092-3.799)$ & 64.7 & 35.7 & $<0.001$ & $(1.014-3.822)$ \\
\hline 1 or $2(n=23)$ & 30.4 & 10.4 & & & 21.7 & 0 & & \\
\hline
\end{tabular}

Bold print indicates statistical significance. CI, confidence Interval; CRP, C-reactive protein; HBsAg, hepatitis B surface antigen; AFP, $\alpha$-fetoprotein; ALT, alanine aminotransferase; AST, aspartate aminotransferase; CA19-9, carbohydrate antigen 19-9; TNM, tumour-nodemetastasis; GPS, Glasgow Prognostic Score.

anti-apoptotic protein myeloid cell leukemia-1 in an either autocrine or paracrine manner $(47,48)$. These are consistent with the significant preoperative increase of IL-6 in the serum of patients with cholangiocarcinoma and its apparent decrease after surgery (49,50). IL-1 family cytokines and TNF also facilitate oncogenesis of cholangiocarcinoma, as previously described (51-53). These may partially underlie the mechanism through which GPS score correlates with the prognosis of ICC patients.

Preoperative serum albumin reflects nutritional status $(54,55)$; it decreases in response to systemic inflammation during malignant tumour growth, leading to hypoalbuminemia and weight loss (56), which may in turn affect the immune system of the cancer patients (57). Hypoalbuminemia therefore suggests systemic inflammation and immune suppression, in association with the initiation and progression of malignant tumours, and has been reported as an independent prognostic marker for ICC (58). These findings explain the correlation of GPS with recurrence and prognosis of ICC patients observed in this study.

Our data indicated that $47.2 \%$ of ICC patients were positive for hepatitis B surface antigen, and these patients generally exhibited longer overall and progression-free survival. Accumulating evidence suggests a correlation of ICC development with HBV infection $(59,60)$. HBV DNA may be detectable in tumour tissues from a proportion of the ICC patients $(61,62)$. Chronic HBV and hepatitis $\mathrm{C}$ virus infection represent risk factors for ICC occurrence based on a meta-analysis of 13 case-control and 3 cohort studies (63). However, ICC patients carrying HBV had a better prognosis compared with those without HBV infection $(64,65)$. This is likely due to a lower tendency for metastasis towards the perihepatic lymph nodes and a higher rate of encapsulation in ICC patients with HBV $(66,67)$. In addition, the immunological memory caused by a previous HBV infection may be quickly activated by the HBV-relevant ICC, promoting antitumour immunity $(68,69)$.

The prognosis of ICC is currently assessed postoperatively by the complicated TNM classification, the Barcelona Clinic Liver Cancer staging system (70), and the Cancer Liver Italian Program scoring system (71). GPS scoring represents a simple and easily applicable method, based on preoperative serum CRP and albumin levels, which may be determined biochemically. The present study revealed a significant correlation between the overall and progression-free survival of ICC patients following resection and their preoperative GPS scores, and supports GPS as an effective and easily achievable prognostic marker for ICC patients.

\section{Acknowledgements}

We would like to thank all the members of the Department of Oncological Surgery of the First Affiliated Hospital of Fujian Medical University for their help and support.

\section{References}

1. Guest RV, Boulter L, Kendall TJ, Minnis-Lyons SE, Walker R, Wigmore SJ, Sansom OJ and Forbes SJ: Cell lineage tracing reveals a biliary origin of intrahepatic cholangiocarcinoma. Cancer Res 74: 1005-1010, 2014.

2. Nakanuma Y, Sripa B, Batanasapt V, Leong ASY, Ponchon T and Ishak KG: Intrahepatic cholangiocarcinoma. In: Pathology and Genetics of Tumours of the Digestive System. World Health Organization of Tumours. Hamilton SR and Aaltonen LA (eds). IARC, Lyon, pp173-180, 2000.

3. Farges O, Fuks D, Le Treut YP, et al: AJCC 7th edition of TNM staging accurately discriminates outcomes of patients with resectable intrahepatic cholangiocarcinoma:by the AFC-IHCC-2009 study group. Cancer 117: 2170-2177, 2011

4. Zou S, Li J, Zhou H, Frech C, Jiang X, Chu JS, Zhao X, Li Y, Li Q, Wang H, et al: Mutational landscape of intrahepatic cholangiocarcinoma. Nat Commun 5: 5696, 2014. 
5. Wang JD and Quan ZW: The molecular mechanism of cholangiocarcinoma. J Pract Oncol Chin 22: 96-98, 2007.

6. de Jong MC, Nathan H, Sotiropoulos GC, Paul A, Alexandrescu S, Marques H, Pulitano C, Barroso E, Clary BM, Aldrighetti L, et al: Intrahepatic cholangiocarcinoma: An international multi-institutional analysis of prognostic factors and lymph node assessment. J Clin Oncol 29: 3140-3145, 2011.

7. de Groen PC, Gores GJ, LaRusso NF, Gunderson LL and Nagorney DM: Biliary tract cancers. N Engl J Med 341: $1368-1378,1999$.

8. Li T, Qin LX, Zhou J, Sun HC, Qiu SJ, Ye QH, Wang L, Tang ZY and Fan J: Staging, prognostic factors and adjuvant therapy of intrahepatic cholangiocarcinoma after curative resection. Liver Int 34: 953-960, 2014.

9. Li H, Wu JS, Wang XT, Lv P, Gong LS, Liu G, Tian BN, Li YY and Jiang B: Factors predicting surgical resection in patients with intrahepatic cholangiocarcinoma and cirrhosis. J Invest Surg 27: 219-225, 2014

10. Wang Y, Li J, Xia Y, Gong R, Wang K, Yan Z, Wan X, Liu G, $\mathrm{Wu} \mathrm{D}$, Shi L, et al: Prognostic nomogram for intrahepatic cholangiocarcinoma after partial hepatectomy. J Clin Oncol 31 1188-1195, 2013.

11. Paik KY, Jung JC, Heo JS, Choi SH, Choi DW and Kim YI: What prognostic factors are important for resected intrahepatic cholangiocarcinoma? J Gastroenterol Hepatol 23: 766-770, 2008.

12. Kinoshita A, Onoda H, Imai N, Iwaku A, Oishi M, Tanaka K, Fushiya N, Koike K, Nishino H, Matsushima M, et al: The Glasgow Prognostic Score, an inflammation based prognostic score, predicts survival in patients with hepatocellular carcinoma BMC Cancer 13: 52, 2013.

13. Roxburgh CS and McMillan DC: Role of systemic inflammatory response in predicting survival in patients with primary operable cancer. Future Oncol 6: 149-163, 2010.

14. Argilés JM, Busquets S, Toledo M and López-Soriano FJ: The role of cytokines in cancer cachexia. Curr Opin Support Palliat Care 3: 263-268, 2009.

15. Balkwill $\mathrm{F}$ and Mantovani A: Inflammation and cancer: Back to Virchow? Lancet 357: 539-545, 2001.

16. Kusumanto YH, Dam WA, Hospers GA, Meijer C and Mulder NH: Platelets and granulocytes in particular the neutrophils from important compartments for circulating vascular endothelial growth factor. Angiogenesis 6: 283-287, 2003.

17. Ulich TR, Del Castillo J and Guo KZ: In vivo hematologic effects of recombinant interleukin- 6 on hematopoiesis and circulating numbers of RBCs and WBCs. Blood 73: 108-110, 1989.

18. Philip M, Rowley DA and Schreiber H: Inflammation as a tumor promoter in cancer induction. Semin Cancer Biol 14: 433-439, 2004.

19. Heikkilä K K, Ebrahim S, Lawlor DA. A systematic review of the association between circulating concentrations of $\mathrm{C}$ reactive protein and cancer. Epidemiol Community Health 61: 824-833, 2007.

20. Kulbe H, Chakravarty P, Leinster DA, Charles KA, Kwong J, Thompson RG, et al: A dynamic inflammatory cytokine network in the human ovarian cancer microenvironment. Cancer Res 72 66-75, 2012.

21. Coward J, Kulbe H, Chakravarty P, Leader D, Vassileva V, Leinster DA, Thompson R, Schioppa T, Nemeth J, Vermeulen J, et al: Interleukin-6 as a therapeutic target in human ovarian cancer. Clin Cancer Res 17: 6083-6096, 2011.

22. Tomita M, Ayabe T, Chosa E and Nakamura K: Prognostic significance of pre- and postoperative glasgow prognostic score for patients with non-small cell lung cancer. Anticancer Res 34: 3137-3140, 2014

23. Jiang AG, Chen HL and Lu HY: Comparison of Glasgow prognostic score and prognostic index in patients with advanced non-small cell lung cancer. J Cancer Res Clin Oncol 141: $563-568,2015$.

24. Sharma R, Hook J, Kumar M and Gabra H: Evaluation of an inflammation-based prognostic score in patients with advanced ovarian cancer. Eur J Cancer 44: 251-256, 2008

25. Ikeguchi M, Urushibara S, Shimoda R, Yamamoto M, Maeta Y and Ashida K: Inflammation-based prognostic scores and nutritional prognostic index in patients with locally-advanced unresectable colorectal cancer. World J Surg Oncol 12: 210 , 2014.

26. Ramsey S, Lamb GW, Aitchison M, Graham J and McMillan DC Evaluation of an inflammation-based prognostic score in patients with metastatic renal cancer. Cancer 109: 205-212, 2007.
27. Pan QX, Zhang JH, Su ZJ, Wang CR and Ke SY: The Glasgow Prognostic Score is an independent prognostic predictor of hepatocellular carcinoma following radical resection. Oncol Res Treat 37: 192-197, 2014

28. Ishizuka M, Kubota K, Kita J, Shimoda M, Kato M and Sawada T: Impact of an inflammation-based prognostic system on patients undergoing surgery for hepatocellular carcinoma: A retrospective study of 398 Japanese patients. Am J Surg 203: 101-106, 2012.

29. Kaneko M, Nozawa H, Sasaki K, Hongo K, Hiyoshi M, Tada N, Murono K, Nirei T, Kawai K, Sunami E, et al: Elevated neutrophil to lymphocyte ratio predicts poor prognosis in advanced colorectal cancer patients receiving oxaliplatin-based chemotherapy. Oncology 82: 261-268, 2012

30. Oh BS, Jang JW, Kwon JH, You CR, Chung KW, Kay CS, Jung HS and Lee S: Prognostic value of C-reactive protein and neutrophil-to-lymphocyte ratio in patients with hepatocellular carcinoma. BMC Cancer 13: 78, 2013

31. Kwon HC, Kim SH, Oh SY, Lee S, Lee JH, Choi HJ, Park KJ, Roh MS, Kim SG, Kim HJ, et al: Clinical significance of preoperative neutrophil-lymphocyte versus platelet-lymphocyte ratio in patients with operable colorectal cancer. Biomarkers 17: 216-222, 2012.

32. Smith RA, Bosonnet L, Raraty M, Sutton R, Neoptolemos JP, Campbell F and Ghaneh P: Preoperative platelet-lymphocyte ratio is an independent significant prognostic marker in resected pancreatic ductal adenocarcinoma. Am J Surg 197: 466-472, 2009.

33. Kasymjanova G, MacDonald N, Agulnik JS, Cohen V, Pepe C, Kreisman H, Sharma R and Small D: The predictive value of pre-treatment inflammatory markers in advanced non-small-cell lung cancer. Curr Oncol 17: 52-58, 2010.

34. Proctor MJ, Morrison DS, Talwar D, Balmer SM, Fletcher CD, O'Reilly DS, Foulis AK, Horgan PG and McMillan DC: A comparison of inflammation-based prognostic scores in patients with cancer. A Glasgow Inflammation Outcome Study. Eur J Cancer 47: 2633-2641, 2011.

35. Pinato DJ, North BV and Sharma R: A novel, externally validated inflammation-based prognostic algorithm in hepatocellular carcinoma: The prognostic nutritional index (PNI). Br J Cancer 106: 1439-1445, 2012.

36. Gomez D, Morris-Stiff G, Toogood GJ, Lodge JP and Prasad KR: Impact of systemic inflammation on outcome following resection for intrahepatic cholangiocarcinoma. J Surg Oncol 97: 513-518, 2008.

37. Oshiro Y, Sasaki R, Fukunaga K, Kondo T, Oda T, Takahashi H and Ohkohchi N: Inflammation-based prognostic score is a useful predictor of postoperative outcome in patients with extrahepatic cholangiocarcinoma. J Hepatobiliary Pancreat Sci 20: 389-395, 2013.

38. Hiraoka A, Kawamura T, Aibiki T, Okudaira T, Toshimori A, Yamago H, Nakahara H, Suga Y, Azemoto N, Miyata H, et al: Prognosis and therapy for ruptured hepatocellular carcinoma: Problems with staging and treatment strategy. Eur J Radiol 84: 366-371, 2015. [J].

39. Edmondson HA and Steiner PE: Primary carcinoma of the liver: A study of 100 cases among 48,900 necropsies. Cancer 7: $462-503,1954$

40. Leyva-Illades D, McMillin M, Quinn M and Demorrow S: Cholangiocarcinoma pathogenesis: Role of the tumor microenvironment. Transl Gastrointest Cancer 1: 71-80, 2012.

41. Dutta S, Crumley AB, Fullarton GM, Horgan PG and McMillan DC: Comparison of the prognostic value of tumour and patient related factors in patients undergoing potentially curative resection of gastric cancer. Am J Surg 204: 294-299, 2012.

42. Wang DS, Ren C, Qiu MZ, Luo HY, Wang ZQ, Zhang DS, Wang FH, Li YH and Xu RH: Comparison of the prognostic value of various preoperative inflammation-based factors in patients with stage III gastric cancer. Tumour Biol 33: 749-756, 2012.

43. Glen P, Jamieson NB, McMillan DC, Carter R, Imrie CW and McKay CJ: Evaluation of an inflammation-based prognostic score in patients with inoperable pancreatic cancer. Pancreatology 6: 450-453, 2006

44. Allin KH and Nordestgaard BG: Elevated C-reactive protein in the diagnosis, prognosis, and cause of cancer. Crit Rev Clin Lab Sci 48: 155-170, 2011.

45. Johnson C, Han Y, Hughart N, McCarra J, Alpini G and Meng F: Interleukin- 6 and its receptor, key players in hepatobiliary inflammation and cancer. Transl Gastrointest Cancer 1: 58-70, 2012.

46. Wehbe H, Henson R, Meng F, Mize-Berge J and Patel T: Interleukin-6 contributes to growth in cholangiocarcinoma cells by aberrant promoter methylation and gene expression. Cancer Res 66: 10517-10524, 2006. 
47. Park J, Tadlock L, Gores GJ and Patel T: Inhibition of interleukin 6-mediated mitogen-activated protein kinase activation attenuates growth of a cholangiocarcinoma cell line. Hepatology 30: 1128-1133, 1999.

48. Meng F, Yamagiwa Y, Ueno Y and Patel T: Over-expression of interleukin-6 enhances cell survival and transformed cell growth in human malignant cholangiocytes. J Hepatol 44: 1055-1065, 2006.

49. Heimbach JK, Gores GJ, Haddock MG, Alberts SR, Nyberg SL, Ishitani MB and Rosen CB: Liver transplantation for unresectable perihilar cholangiocarcinoma. Semin Liver Dis 24 201-207, 2004

50. Jarnagin WR, Fong Y, DeMatteo RP, Gonen M, Burke EC, Bodniewicz BS J, Youssef BA M, Klimstra D and Blumgart LH: Staging, resectability, and outcome in 225 patients with hilar cholangiocarcinoma. Ann Surg 234: 507-517, discussion 517-519, 2001

51. Yamada D, Rizvi S, Razumilava N, Bronk SF, Davila JI, Champion MD, Borad MJ, Bezerra JA, Chen X and Gores GJ: IL-33 facilitates oncogene-induced cholangiocarcinoma in mice by an interleukin-6-sensitive mechanism. Hepatology 61: $1627-1642,2015$

52. Jaiswal M, LaRusso NF, Burgart LJ and Gores GJ: Inflammatory cytokines induce DNA damage and inhibit DNA repair in cholangiocarcinoma cells by a nitric oxide-dependent mechanism. Cancer Res 60: 184-190, 2000.

53. Maemura K, Natsugoe S and Takao S: Molecular mechanism of cholangiocarcinoma carcinogenesis. J Hepatobiliary Pancreat Sci 21: 754-760, 2014.

54. Gupta D and Lis CG: Pretreatment serum albumin as a predictor of cancer survival: A systematic review of the epidemiological literature. Nutr J 9: 69, 2010

55. Lien YC, Hsieh CC, Wu YC, Hsu HS, Hsu WH, Wang LS, Huang MH and Huang BS: Preoperative serum albumin level is a prognostic indicator for adenocarcinoma of the gastric cardia. J Gastrointest Surg 8: 1041-1048, 2004.

56. McMillan DC, Watson WSO, O'Gorman P, Preston T, Scott HR and McArdle CS: Albumin concentrations are primarily determined by the body cell mass and the systemic inflammatory response in cancer patients with weight loss. Nutr Cancer 39: 210-213, 2001

57. Ohki S, Shibata M, Gonda K, Machida T, Shimura T, Nakamura I, Ohtake T, Koyama Y, Suzuki S, Ohto H, et al: Circulating myeloid-derived suppressor cells are increased and correlate to immune suppression, inflammation and hypoproteinemia in patients with cancer. Oncol Rep 28: 453-458, 2012.

58. Nakeeb A, Pitt HA, Sohn TA, Coleman J, Abrams RA, Piantadosi S, Hruban RH, Lillemoe KD, Yeo CJ and Cameron JL: Cholangiocarcinoma. A spectrum of intrahepatic, perihilar, and distal tumors. Ann Surg 224: 463-473, discussion 473-475, 1996.

59. Tanaka M, Tanaka H, Tsukuma H, Ioka A, Oshima A and Nakahara T: Risk factors for intrahepatic cholangiocarcinoma: A possible role of hepatitis B virus. J Viral Hepat 17: 742-748, 2010
60. Donato F, Gelatti U, Tagger A, Favret M, Ribero ML, Callea F, Martelli C, Savio A, Trevisi P and Nardi G: Intrahepatic cholangiocarcinoma and hepatitis $\mathrm{C}$ and $\mathrm{B}$ virus infection, alcohol intake, and hepatolithiasis: A case-control study in Italy. Cancer Causes Control 12: 959-964, 2001

61. Wu Y, Wang T, Ye S, Zhao R, Bai X, Wu Y, Abe K and Jin X: Detection of hepatitis B virus DNA in paraffin-embedded intrahepatic and extrahepatic cholangiocarcinoma tissue in the northern Chinese population. Hum Pathol 43: 56-61, 2012.

62. Perumal V, Wang J, Thuluvath P, Choti M and Torbenson M: Hepatitis $\mathrm{C}$ and hepatitis B nucleic acids are present in intrahepatic cholangiocarcinomas from the United States. Hum Pathol 37: 1211-1216, 2006.

63. Zhou Y, Zhao Y, Li B, Huang J, Wu L, Xu D, Yang J and He J: Hepatitis viruses infection and risk of intrahepatic cholangiocarcinoma: Evidence from a meta-analysis. BMC Cancer 12: 289, 2012.

64. Zhou HB, Wang H, Li YQ, Li SX, Wang H, Zhou DX, Tu QQ, Wang Q, Zou SS, Wu MC, et al: Hepatitis B virus infection: A favorable prognostic factor for intrahepatic cholangiocarcinoma after resection. World J Gastroenterol 17: 1292-1303, 2011.

65. Zhang L, Cai JQ, Zhao JJ, Bi XY, Tan XG, Yan T, Li C and Zhao P: Impact of hepatitis B virus infection on outcome following resection for intrahepatic cholangiocarcinoma. J Surg Oncol 101: 233-238, 2010.

66. Peng NF, Li LQ, Qin X, Guo Y, Peng T, Xiao KY, Chen XG, Yang YF, Su ZX, Chen B, et al: Evaluation of risk factors and clinicopathologic features for intrahepatic cholangiocarcinoma in Southern China: A possible role of hepatitis B virus. Ann Surg Oncol 18: 1258-1266, 2011.

67. Zhou H, Wang H, Zhou D, Wang H, Wang Q, Zou S, Tu Q, Wu M and $\mathrm{Hu} \mathrm{H}$ : Hepatitis B virus-associated intrahepatic cholangiocarcinoma and hepatocellular carcinoma may hold common disease process for carcinogenesis. Eur J Cancer 46: 1056-1061, 2010.

68. Llovet JM, Brú C and Bruix J: Prognosis of hepatocellular carcinoma: The BCLC staging classification. Semin Liver Dis 19: 329-338, 1999.

69. Ding FX, Wang F, Lu YM, Li K, Wang KH, He XW and Sun SH: Multiepitope peptide-loaded virus-like particles as a vaccine against hepatitis B virus-related hepatocellular carcinoma. Hepatology 49: 1492-1502, 2009.

70. Ward SM, Phalora P, Bradshaw D, Leyendeckers H and Klenerman P: Direct ex vivo evaluation of long-lived protective antiviral memory B cell responses against hepatitis B virus. J Infect Dis 198: 813-817, 2008.

71. No authors listed: A new prognostic system for hepatocellular carcinoma: a retrospective study of 435 patients: the Cancer of the Liver Italian Program (CLIP) investigators. Hepatology 28: 751-755, 1998. 